\title{
Salicylates and renal function in rheumatoid arthritis
}

\author{
H C BURRY， P A DIEPPE，F B BRESNIHAN， C BROWN
}

\section{Patients and methods}

Two studies were performed. (1) In a retrospective study we investigated renal function in 20 patients with long-standing $R A$, 10 of whom had received large quantities of salicylate (average total $14.3 \mathrm{~kg}$ ) and 10 of whom had never received systematic salicylate treatment (average total $0 \cdot 125 \mathrm{~kg}$ ). The two groups were matched for age, sex, and duration of disease (table I) and all other drugs taken were recorded. (2) We also performed a prospective study of renal glomerular and tubular function in patients receiving salicylate treatment for the first time. Eight patients with RA and 10 healthy volunteers were observed. Salicylate was administered as aloxiprin two tablets four times daily-a total daily dose of $4 \mathrm{~g}$ of salicylate. Renal function tests were carried out before starting salicylate and again three and 10 days later.

TABLE I-Comparability of patients with $R A$ taking large quantities of salicylates with those taking small quantities

\begin{tabular}{|c|c|c|c|}
\hline & $\begin{array}{l}\text { High- } \\
\text { salicylate } \\
\text { group }\end{array}$ & $\begin{array}{l}\text { Low- } \\
\text { salicylate } \\
\text { group }\end{array}$ & $\begin{array}{c}\text { Significance } \\
\text { of } \\
\text { difference } \\
(t \text {-value })\end{array}$ \\
\hline 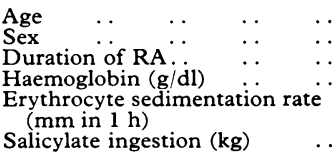 & $\begin{array}{c}55 \cdot 30 \pm 8 \cdot 23 \\
5 \mathrm{M} ; 5 \mathrm{~F} \\
13 \cdot 90 \pm 8 \cdot 34 \\
12 \cdot 24 \pm 0 \cdot 96 \\
35 \cdot 50 \pm 26 \cdot 71 \\
14 \cdot 3\end{array}$ & $\begin{array}{c}54 \cdot 50 \pm 9 \cdot 74 \\
5 \mathrm{M} ; 5 \mathrm{~F} \\
10 \cdot 50 \pm 6 \cdot 96 \\
12 \cdot 52 \pm 1 \cdot 48 \\
43 \cdot 50 \pm 24 \cdot 24 \\
0 \cdot 125\end{array}$ & $\begin{array}{l}0.98 ; \mathrm{NS} \\
0.50 ; \mathrm{NS} \\
0.70 ; \mathrm{NS}\end{array}$ \\
\hline
\end{tabular}

NS $=$ Not significant

Subjects with known renal disease or hypertension were excluded from both studies. The indices analysed in the two studies were: (a) glomerular filtration rate, measured by the ${ }^{51} \mathrm{Cr}$ EDTA clearance method $^{34} ;(b)$ amino-acid excretion; (c) protein excretion; (d) maximum urinary concentration; $(e)$ acid-load handling; $(f)$ epithelial cell and white blood cell excretion; and $(g)$ excretion of $N$-acetyl$\beta$-D-glucosaminidase (NAG). Acid-load handling was evaluated by the method of Wrong and Davies. ${ }^{5}$ Maximum concentrating power was estimated by recording urinary osmolarity after 12 hours' overnight water deprivation and after intramuscular pitressin, 5 units, given at $9 \mathrm{pm}$. The bladder was emptied at 6 am and a specimen collected at 8 am. Epithelial cell and white blood cell counts were expressed per high power field (HPF) from an uncentrifuged specimen of urine and NAG was analysed by the method described by Tucker et $a l^{6}$ and expressed as $\mathrm{nmol} \mathrm{h} \mathrm{h}^{-1} \mathrm{mg}$ creatinine $\mathrm{e}^{-1}$.

\section{Results}

In the retrospective study (table II) there was a significant decrease in maximum urinary concentrating power in the patients who had received high-dose salicylate treatment, although concentrating power was generally lower than normal in both groups. The minimum $\mathrm{pH}$

TABLE II-Results of retrospective study

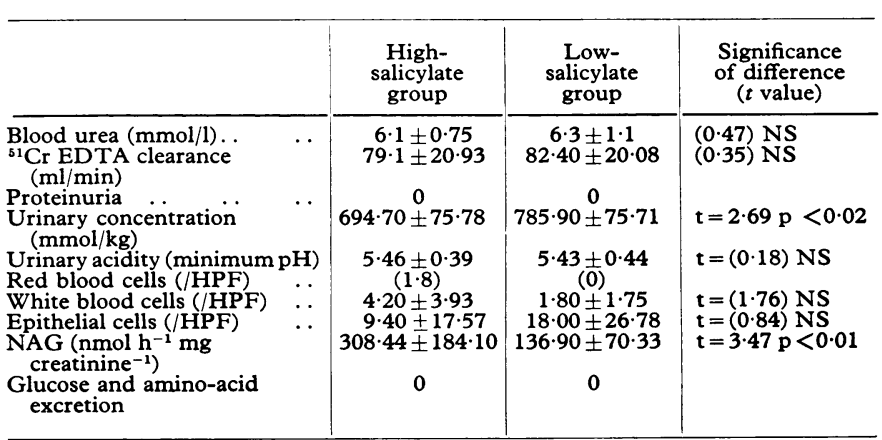

Conversion: SI to traditional units-Urea $1 \mathrm{mmol} / 1 \approx 6 \mathrm{mg} / 100 \mathrm{ml}$. Urinary conConversion: $S I$ to traditional units 
TABLE III-Results of prospective study

\begin{tabular}{|c|c|c|c|c|c|c|c|c|}
\hline & & & \multicolumn{3}{|c|}{ Patients with RA } & \multicolumn{3}{|c|}{ Normal subjects } \\
\hline & & & 1st day & 3rd day & 10th day & 1st day & 3rd day & 10th day \\
\hline 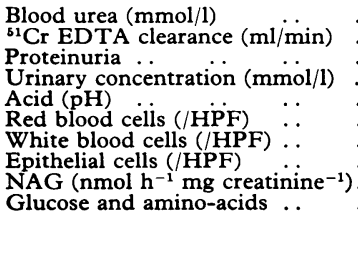 & $\begin{array}{l}\cdots \\
\cdots \\
\because \\
\cdots \\
\cdots \\
\cdots \\
\cdots\end{array}$ & $\begin{array}{l}\because \\
\therefore \\
\because \\
\because \\
\therefore \\
\therefore \\
\therefore \\
\therefore\end{array}$ & $\begin{array}{c}5 \cdot 3 \pm 0 \cdot 73 \\
91 \cdot 56 \pm 20 \cdot 26 \\
0 \\
680 \cdot 12 \pm 104 \cdot 19 \\
5 \cdot 2 \\
1 \cdot 6 \\
5 \cdot 50 \pm 10 \cdot 62 \\
8 \cdot 62 \pm 8 \cdot 63 \\
127 \cdot 75 \pm 72 \cdot 4 \\
0\end{array}$ & $\begin{array}{rl}5 \cdot 5 & \pm 0 \cdot 59 \\
88 \cdot 32 & \pm 16 \cdot 49 \\
0 & \\
742 \cdot 25 & \pm 130 \cdot 58 \\
5 \cdot 3 & 7 \cdot 6 \\
12 \cdot 25 & \pm 17 \cdot 8 \\
34 \cdot 12 & \pm 51 \cdot 97 \\
279 \cdot 75 & \pm 201 \cdot 91 \\
0 & \end{array}$ & $\begin{aligned} & 5 \cdot 2 \pm 0 \cdot 95 \\
& 89 \cdot 75 \pm 17 \cdot 43 \\
& 0 \\
& 783 \cdot 12 \pm 84 \cdot 68 \\
& 5 \cdot 2 \\
& 1 \cdot 6 \\
& 5 \cdot 14 \pm 10 \cdot 14 \\
& 14 \cdot 00 \pm 18 \cdot 27 \\
& 259 \cdot 38 \pm 86 \cdot 24 \\
& 0\end{aligned}$ & $\begin{array}{c}5 \cdot 8 \pm 0 \cdot 93 \\
118 \cdot 98 \pm 16 \cdot 51 \\
0 \\
907 \cdot 4 \\
5 \cdot 1 \\
2 \cdot 0 \\
0 \cdot 8 \\
4 \cdot 70 \pm 8 \cdot 06 \\
35 \cdot 40 \pm 10 \cdot 75 \\
0\end{array}$ & $\begin{array}{c}6.4 \pm 1 \cdot 2 \\
123 \cdot 82 \pm 22 \cdot 71 \\
0 \\
916 \cdot 6 \\
5 \cdot 2 \\
1.9 \\
5 \cdot 2 \\
15 \cdot 90 \pm 10 \cdot 30 \\
151 \cdot 9 \pm 48 \cdot 59 \\
\text { Increase in basic } \\
\text { amino-acids in } 2 \\
\text { subjects }\end{array}$ & $\begin{array}{c}\left.\begin{array}{c}6 \cdot 0 \pm 0.92 \\
139 \cdot 08 \pm 19 \cdot 44 \\
0 \\
886 \cdot 4 \\
5 \cdot 1\end{array}\right\} 5 \text { subjects } \\
1 \cdot 1 \\
1 \cdot 5 \\
\begin{array}{c}3 \cdot 10 \pm 4 \cdot 06 \\
126 \cdot 5 \pm 43.98 \\
0\end{array}\end{array}$ \\
\hline
\end{tabular}

recorded in both groups was higher than might have been expected, but in both groups the results were affected by the difficulty that some subjects had in ingesting the acid load. The average excretion of NAG was high in both groups (the upper limit of normal is accepted as $100 \mathrm{nmol} \mathrm{h}^{-1} \mathrm{mg}$ creatinine $\left.{ }^{-1}\right),{ }^{6}$ but the high-salicylate group had significantly higher levels. No significant differences were observed in glomerular filtration rate (GFR), cellular excretion, or protein, amino-acid, or glucose excretion.

In the prospective study (table III) no significant changes were found in glomerular or tubular function in either the normal subjects or the patients with RA, but a significant increase in epithelial cell desquamation was observed in both groups at the third day $(P<0.01)$. This rise in excretion rate was not maintained and the level had fallen to normal by the 10th day. Conversely, NAG excretion, which also rose sharply on the third day ( $P<0.01$ in both groups), remained significantly raised at the 10th day ( $P<0.01$ in both groups) (see fig).

\section{Discussion}

Previous evidence that salicylate may damage the kidney includes an increased rate of epithelial cell excretion, ${ }^{7} 8$ transient increases in the excretion of enzymes (not necessarily of renal origin) such as alkaline phosphatase, aspartate aminotransferase, and lactic acid dehydrogenase, ${ }^{9}$ defective concentrating capacity and acidification with defects in sodium potassium and hydrogen ion excretion, ${ }^{10} 11$ and a transient fall in GFR after salicylate infusion. ${ }^{12}{ }^{13}$ There has been no evidence of possible long-term effects. In rats papillary necrosis was quite common ${ }^{14}$ after salicylate ingestion, particularly in conditions of hydropenia, but differences in renal architecture make extrapolation of these results to man hazardous. Epidemiological studies of patients with RA treated with salicylates, such as that conducted by the New Zealand Rheumatism Association, ${ }^{15}$ have not shown that these patients have a higher incidence of renal disease than those receiving other forms of treatment.

These studies did not look closely at tubular function, however, and as the earliest lesions of analgesic nephropathy are in the ascending limb of the loop of Henle, and the upper nephron is affected only at a late stage in the disease, ${ }^{16}$ tubular functional changes may have been overlooked.

Our results seem to indicate that salicylate treatment does have a significant toxic effect on the epithelial cells of the nephron but this results in only minimal impairment of tubular function. They confirm other workers' observations of a transient increase in epithelial cell excretion rate after salicylate ingestion, but the sustained rise in NAG excretion suggests that some continuing damage is taking place, and, although we could discern no impairment of function in the short-term study, the results of the retrospective study suggest that when a large amount of salicylate has been consumed over many years an appreciable degree of tubular functional impairment results. As Ellis $e t a l^{17}$ found that urinary NAG excretion and impairment of concentrating power correlated well with experimental papillary necrosis in dogs, some degree of papillary damage in our patients may have been expected. The design of the experiment excluded the possibility that this impairment was the result of rheumatoid disease itself as the groups were well matched in severity of the disease, age, and sex.

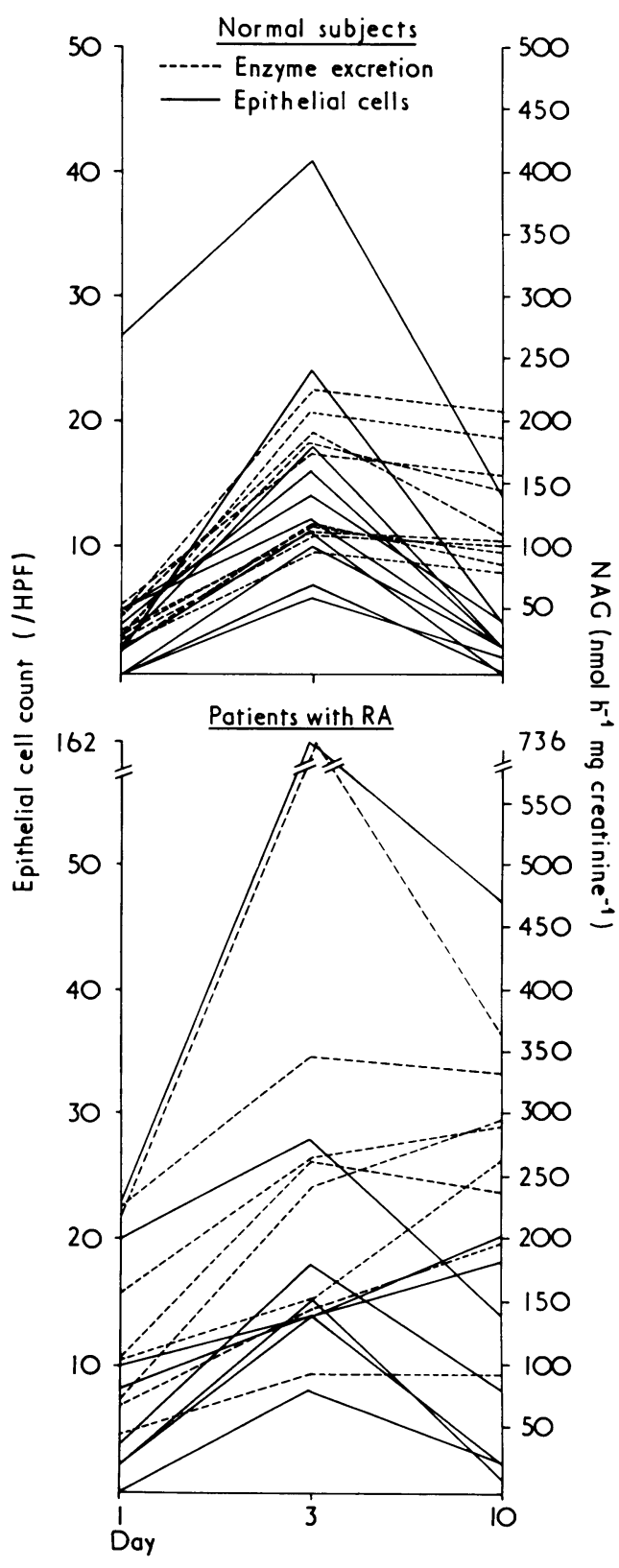

Variation in epithelial cell and enzyme excretion with salicylate treatment in normal subjects and patients with rheumatoid arthritis.

In the retrospective study the use of other drugs such as gold, penicillamine, corticosteroids, and non-steroidal anti-inflammatory drugs was analysed. Although there were slightly more patients who had received chrysotherapy in the salicylate-treated group, analysis of the figures for NAG excretion and maximum concentrating power did not suggest that this form of treatment 
TABLE IV-Effect of gold treatment on mean NAG excretion and maximum concentrating power

\begin{tabular}{|c|c|c|c|c|}
\hline & \multicolumn{2}{|c|}{$\begin{array}{c}\text { Low-salicylate group } \\
(\mathbf{n}=10)\end{array}$} & \multicolumn{2}{|c|}{$\begin{array}{l}\text { High-salicylate group } \\
\qquad(\mathrm{n}=10)\end{array}$} \\
\hline & Gold $(n=3)$ & $\begin{array}{c}\text { No } \\
\text { gold }(n=7)\end{array}$ & Gold $(n=7)$ & $\begin{array}{l}\text { No } \\
\text { gold }(n=3)\end{array}$ \\
\hline NAG (nmol h-1 mg & 67 & 101 & 241 & 263 \\
\hline $\begin{array}{l}\text { Concentrating power } \\
(\mathrm{mmol} / \mathrm{l})\end{array}$ & 795 & 784 & 687 & 713 \\
\hline
\end{tabular}

caused impairment of medullary function (table IV) and the same was found for corticosteroids. A study of NAG excretion in patients with non-inflammatory joint disease has shown that non-steroidal anti-inflammatory drugs do not increase enzyme excretion, ${ }^{18}$ and possibly also there is some form of continuing renal damage in patients with RA irrespective of their treatment. ${ }^{19}$ It seems that salicylate may cause a mild disturbance of function in addition to this. The functional changes would be consistent in severity with the evidence of chronic interstitial nephritis seen in biopsy and necropsy material. Nevertheless, in view of the lack of evidence that salicylates cause any severe renal damage there is no need to deny patients their undoubted therapeutic benefits because of the fear of causing renal damage.

\section{References}

1 Duthie, J J R, et al, Annals of the Rheumatic Diseases, 1964, 23, 193.

2 Lawson, A A H, and Maclean, N, Annals of the Rheumatic Diseases, 1966, 25,441 .

${ }^{3}$ Garnett, E S, Parsons, V, and Veall, N, Lancet, 1967, 1, 818.

4 Chantler, C, Clinical Science, 1969, 37, 169.

${ }^{5}$ Wrong, O, and Davies, H E F, Quarterly fournal of Medicine, 1959, 110, 259.

${ }^{6}$ Tucker, S M, et al, Clinica Chimica Acta, 1975, 62, 333.

7 Scott, J T, Denman, A M, and Dorling, J, Lancet, 1963, 1, 344.

8 Prescott, L F, Lancet, 1965, 2, 91.

${ }^{9}$ Leatherwood, P D, and Plummer, D T, Biochemical fournal, 1969, 114, 197.

${ }^{10}$ Levy, G, and Leonards, J R, in The Salicylates, ed M J H Smith, and P K Smith, p 5. New York, Wiley, 1966.

11 Steele, T W, Gyory, A Z, and Edwards, K D G, British Medical fournal, $1969,2,213$.

12 Beeley, L, and Kendall, M J, British Medical fournal, 1971, 1, 707.

13 Robert, M, et al, British Medical fournal, 1972, 2, 467.

14 Nanra, R S, Chirawong, P, and Kincaid-Smith, P, Renal Infection and Renal Scarring, p 347. Melbourne, Mercedes, 1971.

15 New Zealand Rheumatism Association, British Medical fournal, 1974, 1 , 593.

${ }^{16}$ Burry, A F, Nephron, 1968, 5, 185.

17 Ellis, B G, Price, R G, and Topham, J C, Chemical Biological Interactions, 1973, 7, 101.

18 Dieppe, P A, et al, Rheumatology and Rehabilitation, 1975, 14, 226

19 Dieppe, P A, Tucker, S M, and Burry, H C, Scandinavian fournal of Rheumatology, 1975, 4, suppl 8, abstract No 28-03.

\title{
Failure of BCG immunostimulation to affect the clinical course of Burkitt's lymphoma
}

\author{
I T MAGRATH, J L ZIEGLER
}

British Medical fournal, 1976, 1, 615-618

\begin{abstract}
Summary
A controlled randomised trial was carried out to evaluate the efficacy of BCG immunotherapy in preventing relapse in patients with Burkitt's lymphoma in whom remission had been induced with cyclophosphamide. Twenty-one patients were treated with BCG, and 19 were controls. Eleven patients in each group relapsed during a follow-up period long enough to make it unlikely that further relapses would occur. There were no significant differences in the length of remission or the site of relapse that could be attributed to treatment. Eleven patients died: of these none of the six patients in the BCG group but all of the five in the control group had stage D lymphomas.

BCG treatment increased the rate of recovery from tumour-induced immunosuppression, but within the BCG group immunocompetence improved most rapidly in the patients who relapsed-a finding that appears to contradict the tenet rationalising the use of immunological adjuvants as treatment.
\end{abstract}

Lymphoma Treatment Centre, Makerere University Medical School, Uganda Cancer Institute, Kampala, Uganda

I T MAGRATH, MB, MRCP, director, Lymphoma Treatment Centre (present address: Paediatric Oncology Branch, National Cancer Institute, Bethesda, Maryland, USA)

J L ZIEGLER, MD, director, Uganda Cancer Institute (present address: Paediatric Oncology Branch, National Cancer Institute, Bethesda, Maryland, USA)
These results provide no evidence that BCG has a therapeutically beneficial effect on a tumour which, theoretically, should respond to non-specific immunotherapy. Rather, some of the results indicate that BCG treatment may actually have been deleterious.

\section{Introduction}

Burkitt's lymphoma responds dramatically to chemotherapy, and the high frequency of sustained remission indicates that a cure is possible. ${ }^{1}$ Nevertheless, about two-thirds of patients relapse during the first year, and about half of these eventually die with a tumour resistant to chemotherapy. ${ }^{12}$ Attempts to prevent relapse by intensifying chemotherapy have so far proved unsuccessful. ${ }^{134}$ Evidence for the existance of tumourdirected immunological reactions and their correlation with clinical status ${ }^{6-9}$ prompted us to evaluate immunotherapy in a controlled randomised trial. We report here the effect of nonspecific immunostimulation with BCG on the clinical course of patients in whom remission had been induced by a standard moderate amount of chemotherapy.

\section{Patients and methods}

CLINICAL TRIAL

All patients with untreated Burkitt's lymphoma admitted to the Lymphoma Treatment Centre, Kampala, from February 1971 to July 1973 were included in the trial. The diagnosis of Burkitt's lymphoma was established according to the criteria of the World Health Organisation ${ }^{10}$ by histological examination and cytology of imprints or fine-needle tumour aspirates. ${ }^{11}$ Tumour sites were determined by clinical and radiological examination ${ }^{14}$ and examination of cerebrospinal fluid (CSF) for tumour cells. Tumours were 